\title{
Obesity as an Epidemic: Causes, Morbidities and Reproductive Performance
}

\author{
E. Hakan Duran, M.D. ${ }^{1}$ \\ Key Words: Obesity
}

\begin{abstract}
Obesity is an epidemic causing significant morbidity and mortality in United States. It is facilitated by many factors including sedentary life style, abundance of food, and unhealthy dietary habits. This review aims to briefly address causes and conditions associated with obesity, with a special emphasis on reproductive performance for Obstetricians and Gynecologists.

${ }^{1}$ Division of Reproductive Endocrinology and Infertility, Department of Obstetrics and Gynecology, Carver College of Medicine, University of lowa Hospitals and Clinics, lowa City, IA
\end{abstract}

\section{Definition of Obesity}

Obesity is defined by both National Institutes of Health (NIH) and World Health Organization (WHO)as having a body mass index (BMI) equal to or greater than $30 \mathrm{~kg} / \mathrm{m}^{2}$. ${ }^{1,2}$ The degree of obesity is significantly associated with metabolic and cardiovascular comorbidities, including type 2 diabetes mellitus, hypertension, coronary heart disease, and sleep apnea (Table 1). Coexistence of these conditions will place patients in a very high-risk category for subsequent mortality. ${ }^{3}$ Other morbidities associated with obesity include osteoarthritis, cholelithiasis, and impaired quality of life. Overall, obesity is associated with a striking reduction in life expectancy for both men and women, in younger and older ages. ${ }^{4,5}$

Obesity is a chronic disease with increasing prevalence in adults, adolescents and children. It is now considered a global epidemic. In the United States, the lifetime risk of becoming overweight and obese is approximately $50 \%$ and $25 \%$, respectively. ${ }^{6}$ As of 2009 , overall selfreported obesity prevalence in the United States was $26.7 \%$, disproportionally affecting non-Hispanic blacks (36.8\%), Hispanics (30.7\%), those who did not graduate from high school (32.9\%), and people aged 50-59 years $(31.1 \%)$ and $60-69$ years $(30.9 \%)$ (Figure 1). ${ }^{7}$ Healthcare expenses are significantly higher for overweight and obese individuals, and on average, obese people have medical costs that

Please cite this paper as: Duran, EH. Obesity as an Epidemic: Causes, Morbidities and Reproductive Performance Proc Obstet Gynecol. 2011 Apr;1(3):Article 8[16 p.]. Available from: http://ir.uiowa.edu/pog/. Free full text article.

Corresponding author: E. Hakan Duran. Department of Obstetrics and Gynecology, University of lowa, 31322 PFP, 200 Hawkins Drive, lowa City, IA, 52242. Telephone(319)356-4119. hakan-duran@uiowa.edu

This is an Open Access article distributed under the terms of the Creative Commons Attribution 3.0 Unported License (http://creativecommons.org/licenses/by/3.0), which permits unrestricted use, distribution, and reproduction in any medium, provided the original work is properly cited. 
are $\$ 1,429$ more than non-obese people, translating to an estimated annual cost of $\$ 147$ billion in the United States.

Table 1: Classification of obesity

\begin{tabular}{lccc}
\hline WHO Class & Popular Description & BMI $\left(\mathbf{k g} / \mathrm{m}^{2}\right)$ & Co-morbidities \\
\hline Underweight & Thin & $<18.5$ & Other clinical problems \\
Normal range & Normal & $18.5-24.9$ & Average \\
Overweight & & & \\
\multicolumn{1}{c}{ Pre-obese } & Overweight & $25.0-29.9$ & Increased \\
Obese Class I & Obese & $30.0-34.9$ & Moderate \\
Obese Class II & Obese & $35.0-39.9$ & Severe \\
\multicolumn{1}{c}{ Obese Class III } & Morbidly obese & $>40.0$ & Very severe \\
\hline
\end{tabular}

Figure 1: Prevalence of obesity in US adults by state in $2009^{1}$

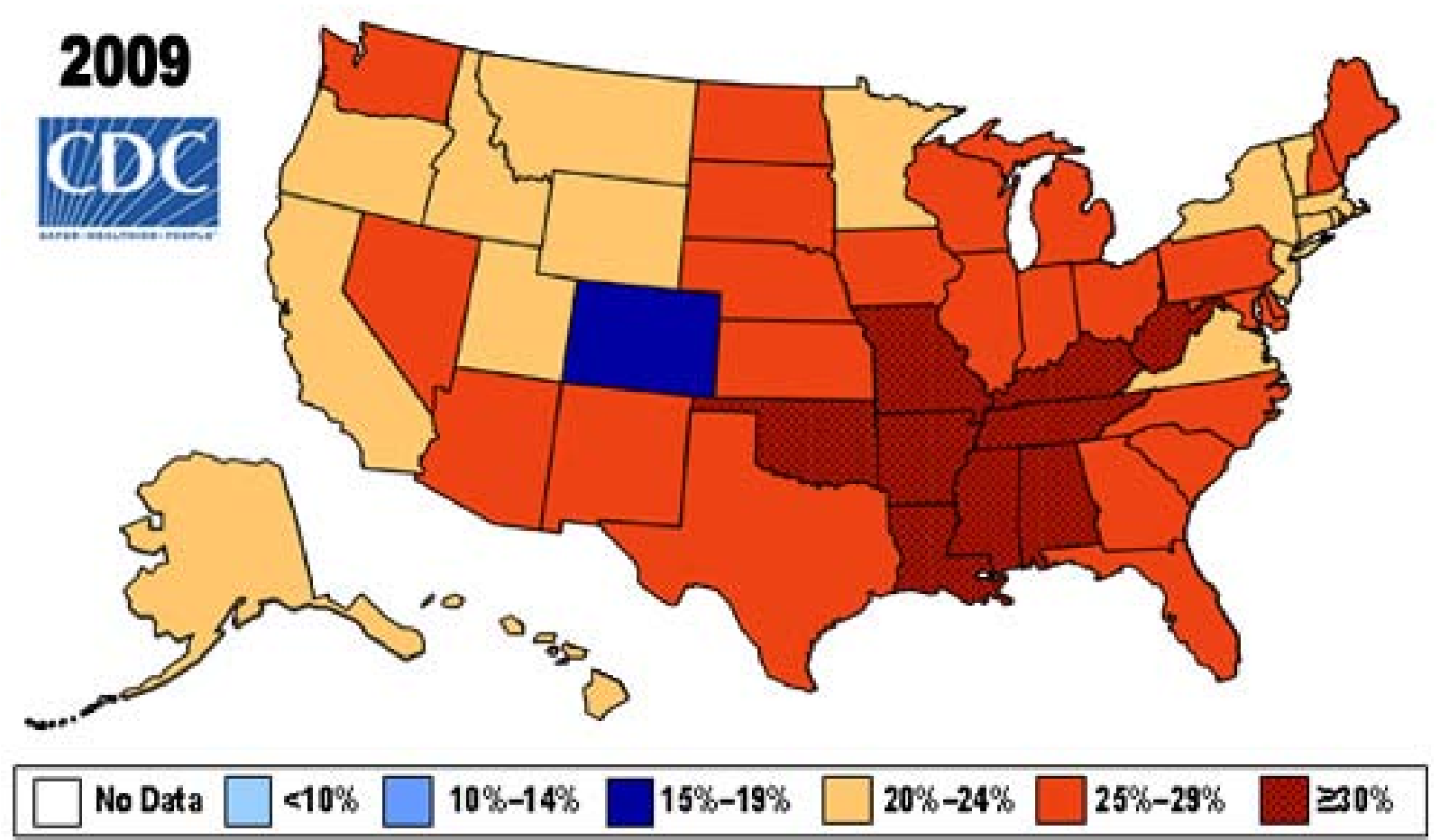

${ }^{1}$ Centers for Disease Control and Prevention. U.S. Obesity Trends: Trends by State 1985-2009.

http://www.cdc.gov/obesity/data/trends.html. March 2011.

\section{Physiologic Basis for Obesity}

Simply put, energy intake needs to be higher than energy expenditure for an increase in body fat. However, there is a feedback between energy intake and expenditure in biological systems, which is affected by several factors including intrauterine growth and growth and reproductive hormones. This complicated modulation of energy utilization and storage reduces the initial statement of the first law of thermodynamics to an oversimplification. The body typically responds to a $10-20 \%$ loss in weight by 
decreasing total and resting energy expenditures; weight gain is associated with an increase in energy expenditure, which retards further weight gain.8 Therefore, organisms seem to have a mechanism that tries to maintain bodyweight, indicating that behavior may not be the sole determinant of obesity.

Approximately $70 \%$ of energy expenditure is utilized for basal or resting metabolic processes, $10 \%$ is dissipated through the thermic responses to food, and the remaining component is attributed to activity and exercise. ${ }^{9}$ Spontaneous activity (fidgeting) can account for an expenditure of up to $800 \mathrm{kcal}$ daily and, along with the genetic factors, is responsible for much of the variance in energy expenditure among individuals.

A simplified schematic representation of energy regulation is presented in Figure $2 .{ }^{10}$ Afferent signals provide information about the deficits or excesses of nutrients and also include neural circuits and circulating hormones, such as leptin, ghrelin, obestatin, and glucagonlike-peptide-1. Regions of the brain that process this information are the nucleus of the tractus solitarius, the arcuate nucleus, the paraventricular nucleus, the ventromedial hypothalamus, the lateral hypothalamus, and selected regions of the amygdala. A variety of monoamines, including norepinephrine and serotonin, and hormones play various roles in this system. Among these, neuropeptide $\mathrm{Y}$, ghrelin, dynorphin, melaninconcentrating hormone, growth hormone-releasing hormone, norepinephrine, orexin-A, and orexin-B act as appetite enhancers. In contrast, cholecystokinin, enterostatin, and peptide YY 3-36 suppress food intake.
The sympathetic nervous system and glucocorticoids also act as components of the efferent signaling system, affecting food intake and adipose tissue metabolism. Leptin is the principal afferent signal that provides information about the amount of stored energy in adipose tissue.

\section{Pathogenesis of Obesity}

Obesity has many causes with variable genetic components. ${ }^{11}$ Twins raised separately still inherit obesity, although to a lesser extent than when raised together. $^{12}$ Similarly, adoptees' BMIs correlate with that of their biological parents rather than that of their adoptive parents. ${ }^{13}$ In addition to weight, metabolic rate, thermic response to food, and spontaneous physical activity are to some extent heritable. ${ }^{14}$

Several genetic disorders present with obesity; some are inherited as autosomal dominant, some are autosomal recessive, whereas others are X-linked. ${ }^{11}$ The Bardet-Biedl and Prader-Willi syndromes are probably the best known examples of these traits. Bardet-Beidl syndrome is an autosomal recessive disorder characterized by obesity, hypogenitalism in men, mental retardation, retinal dystrophy, polydactyly, and renal malformations. ${ }^{15}$ At least 10 genetic loci have been identified in patients with this syndrome. Prader-Willi syndrome, on the other hand, is caused either by a deletion of paternal DNA in the long arm of chromosome 15 (q11-13), or by the presence of two copies of maternal chromosome $15 \quad$ (uniparental disomy). ${ }^{16,17}$ Affected patients have poor muscle tone, a history of poor feeding in the newborn period, a voracious appetite later in life, 
behavioral problems (irritability, tantrums), delayed development, short stature, and hypogonadotropic hypogonadism with a common occurrence of cryptorchidism in boys and primary amenorrhea in girls. ${ }^{18}$ Despite the well-defined nature of these genetic syndromes, they are rare and genes contributing to the more common forms of obesity are yet to be determined. Several candidate genes have been identified and are currently under investigation with the hopes of understanding the causes of the more common types of obesity.

\section{Obesity Risk Factors}

The risk factors associated with a high risk of obesity can be roughly categorized as metabolic and socioeconomic. Metabolic factors include a low metabolic rate, increased carbohydrate oxidation, insulin resistance, and low sympathetic activity. Socioeconomic factors include a lower socioeconomic class, a lower education level, and cessation of smoking. ${ }^{19,20}$

There are several predictors of obesity starting from the prenatal period to adulthood. Infants born to women with diabetes and infants born to women who smoked during pregnancy are at greater risk for obesity later in life. Similarly, both infants born small for gestational age and those in the top $10^{\text {th }}$ percentile of birth weight are at greater risk for obesity. Breastfeeding for three or more months seems to be a good preventive strategy to prevent obesity later in life. ${ }^{21}$ A list of risk factors identified to predict development of obesity is presented in Box 1.22

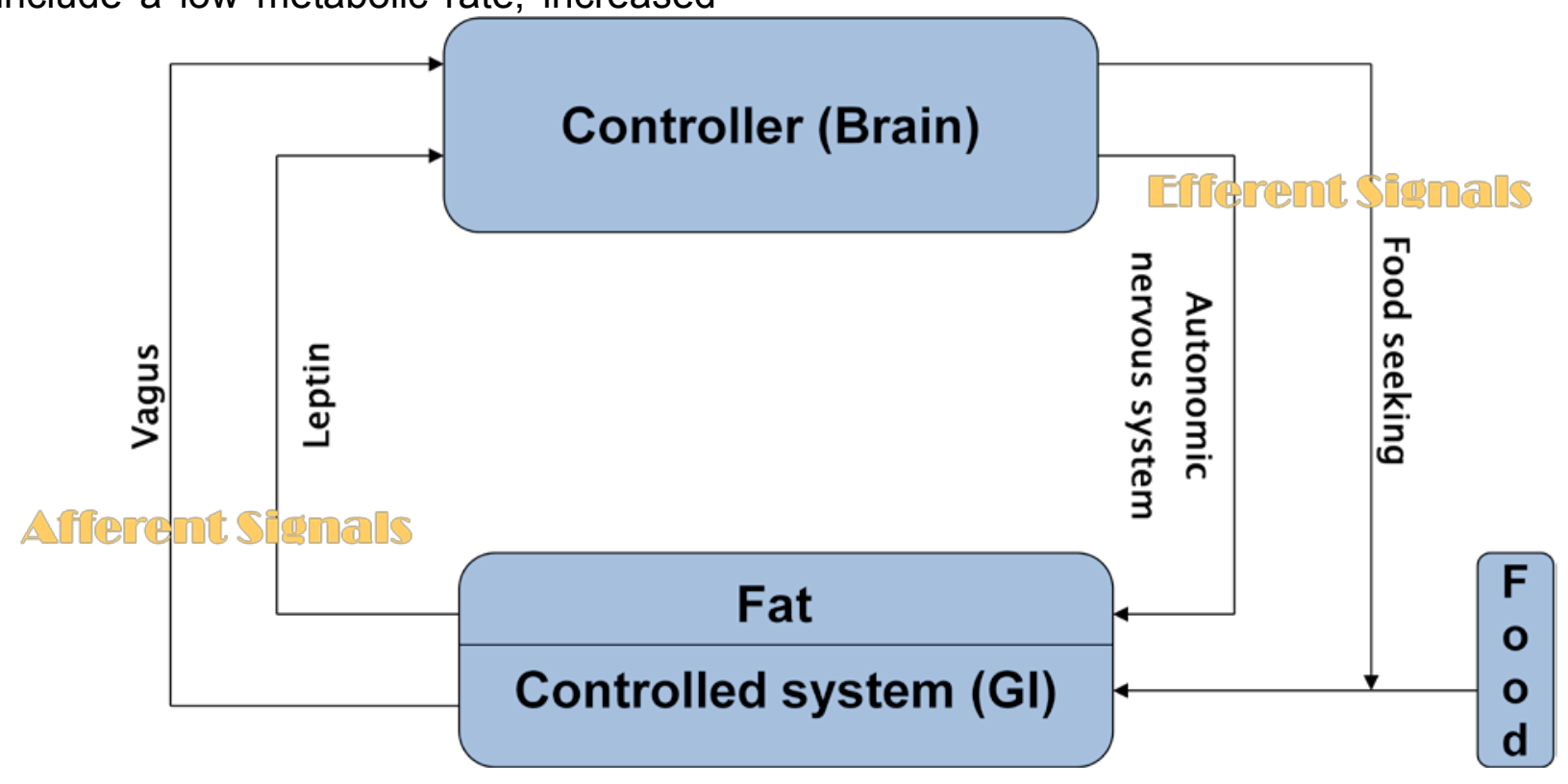

Figure 2: Feedback model for body energy regulation (modified from reference (10)) 
Table 2: Drugs causing weight gain and their alternatives

\begin{tabular}{|c|c|c|}
\hline Category & Drug & Alternative \\
\hline Neuroleptics & $\begin{array}{l}\text { Thioridazine, olanzapine, } \\
\text { quetiapine, risperidone, } \\
\text { clozapine }\end{array}$ & $\begin{array}{l}\text { Molindone, haloperidol, } \\
\text { aripiprazole }\end{array}$ \\
\hline \multicolumn{3}{|l|}{ Antidepressants } \\
\hline Tricyclics & $\begin{array}{l}\text { Amitriptyline, nortriptyline, } \\
\text { imipramine }\end{array}$ & Protriptyline \\
\hline SSRI & Paroxetine & Sertraline, fluoxetine \\
\hline Other & Mitrazapine & Bupropion, nefazodone \\
\hline Anticonvulsants & $\begin{array}{l}\text { Valproate, carbamazepine, } \\
\text { gabapentin }\end{array}$ & $\begin{array}{l}\text { Topiramate, lamotrigine, } \\
\text { zonisamide }\end{array}$ \\
\hline Antidiabetics & $\begin{array}{l}\text { Insulin, sulfonylureas, } \\
\text { thiazolidinediones }\end{array}$ & $\begin{array}{l}\text { Acarbose, miglitol, metformin, } \\
\text { pramlintide, exenatide }\end{array}$ \\
\hline Antiserotonins & Pizotifen & - \\
\hline Antihistamines & Cyproheptadine & Inhalers, decongestants \\
\hline$\beta$-blockers & $\begin{array}{l}\text { Propranolol, atenolol, } \\
\text { metoprolol }\end{array}$ & $\begin{array}{l}\text { ACE inhibitors, Ca channel } \\
\text { blockers }\end{array}$ \\
\hline$\alpha$-blockers & Terazosin & $\begin{array}{l}\text { ACE inhibitors, Ca channel } \\
\text { blockers }\end{array}$ \\
\hline Steroid hormones & Corticosteroids, progestins & - \\
\hline
\end{tabular}

Box 1: Risk factors for development of obesity

\begin{tabular}{|c|c|}
\hline \multicolumn{2}{|c|}{ Risk Factors } \\
\hline • & Infants born to women who smoked during pregnancy \\
\hline$\bullet$ & Infants born to women with diabetes \\
\hline • & Multiple births \\
\hline$\bullet$ & Premature births \\
\hline • & Small for gestational age infants \\
\hline$\bullet$ & Large for gestational age infants \\
\hline$\bullet$ & Recent marriage \\
\hline$\bullet$ & Smoking cessation \\
\hline$\bullet$ & Parental overweight \\
\hline$\bullet$ & Lower socioeconomic status \\
\hline$\bullet$ & Overweight during childhood or adolescence \\
\hline$\bullet$ & Lack of maternal knowledge of child's sweet-eating habits \\
\hline$\bullet$ & Low level of physical activity \\
\hline$\bullet$ & High intake of dietary fat \\
\hline$\bullet$ & Infants breastfed for less than 3 months \\
\hline$\bullet$ & Pregnancy \\
\hline$\bullet$ & Menopause \\
\hline
\end{tabular}




\section{Conditions Causing Obesity}

Other than the well-defined genetic syndromes some of which were stated above, there are several clinical entities that may result in obesity without producing distinctive phenotypes.

\section{Neuroendocrine Obesity}

\section{a) Hypothalamic Obesity}

Hypothalamic obesity may be produced in animals by injuring the ventromedial or paraventricular region of the hypothalamus or the amygdala, but it is rare in humans. It may be caused in humans by trauma, tumor, inflammatory disease, surgery in the posterior fossa or increased intracranial pressure.

\section{b) Cushing's syndrome}

Obesity is a major feature of Cushing's syndrome. However, a variety of conditions may mimic Cushing's syndrome by distorting the hypothalamic-pituitary-adrenal axis; manifestations include depression, anxiety disorder, obsessive-compulsive disorder, poorly controlled diabetes, and alcoholism, and the condition is referred to as pseudo-Cushing's syndrome. Although it may be challenging at times to differentiate these two conditions from each other, it is necessary to address the underlying problem appropriately.

\section{c) Hypothyroidism}

Weight gain associated with hypothyroidism is secondary to the slowing metabolic activity and typically does not lead to marked obesity. It is more prevalent in older women.

\section{a) Polycystic Ovary Syndrome}

Polycystic ovarian syndrome (PCOS) is a spectrum of conditions characterized by menstrual irregularities, hyperandrogenism and/or ultrasonographic appearance of polycystic ovaries. ${ }^{23}$ It is believed to affect $6-8 \%$ of all women. ${ }^{24,25}$ Approximately $60 \%$ of women in United States with PCOS are obese ${ }^{26}$ Similarly, $50-70 \%$ of women with PCOS have clinically measurable insulin resistance in vivo, which is more than what is determined by their body weight. It is clear that environmental factors play part in determining the presence and degree of obesity in PCOS; however it is also possible that PCOS is associated with a greater propensity for obesity and weight gain.

\section{d) Growth Hormone Deficiency}

Growth hormone selectively decreases visceral fat and may be a factor in the age-related increase in visceral fat since the level of growth hormone gradually decreases with age. Women and children with growth hormone deficiency exhibit an increase in visceral fat, although this increase does not lead to clinical obesity.

\section{Drug Induced Weight Gain}

A brief list of drugs that may cause weight gain is presented in Table $2 .^{22}$ Most of these medications are not sufficient to cause obesity on their own, except high dose corticosteroids, psychoactive drugs or valproate.

\section{Cessation of Smoking}

Weight gain after cessation of smoking is common and at least partly mediated by nicotine withdrawal. ${ }^{27,28}$ The odds ratio of obesity by smoking cessation is estimated to be 2.4 in men and 2.0 in women. Therefore, all patients who plan to quit smoking should consider an exercise program and decreased caloric intake. 


\section{Sedentary Life Style}

Restriction of physical activity is probably the most important contributor to obesity, even more so than increased food intake. The highest frequency of overweight individuals occurs in those persons with sedentary occupations. Low levels of physical activity and recreation are related to weight gain. ${ }^{29}$ In addition, high levels of physical activity are required to maintain normal body weight in middle age years. ${ }^{30}$ Similarly, BMI of children is positively correlated with the hours spent watching television. ${ }^{31}$ Just reducing TV viewing, without any other intervention, significantly reduces $\mathrm{BMI}$ in children. ${ }^{32}$

\section{Dietary Factors}

Excess energy intake in relation to energy expenditure is the basis for development of obesity. Several dietary factors that may impact this balance are listed below.

\section{a) Overeating}

Voluntary overeating is one cause of excess energy intake. Some individuals may actually lose all the weight they have gained once they stop overeating, whereas for others weight gain can reach a rate of nearly $25 \mathrm{~kg} / \mathrm{year}$ and is sustained until death.

\section{b) Fat Intake}

High fat content in a diet is associated with obesity, as indicated by a positive correlation between relative weight in several populations and the percentage of fat in their diets. ${ }^{33}$ A high-fat diet provides a high energy density (i.e., lesser weight of food for the same amount of calories), which makes overconsumption more likely.

\section{c) Carbohydrate and Fiber Intake}

The glycemic index is a measure of the effects of carbohydrates on blood sugar levels. Carbohydrates that break down quickly during digestion and release glucose rapidly into the bloodstream have a high glycemic index; carbohydrates that break down more slowly, releasing glucose more gradually into the bloodstream, have a low glycemic index. It has been documented that the consumption of foods with a high glycemic index is associated with higher energy intake than when the foods have a low glycemic index. ${ }^{34}$ Foods with low glycemic index also stimulate less food intake. Consumption of sugar-sweetened beverages, which typically have a high glycemic index, by children may enhance the risk of rapid weight gain. ${ }^{35}$

\section{d) Calcium Intake}

Low calcium intake may facilitate weight gain. Increasing supplemental calcium from $0 \mathrm{mg}$ to nearly $2,000 \mathrm{mg}$ daily was associated with a reduction in BMI of approximately 5 units. $^{36}$

\section{e) Frequency of Eating}

Although not completely established, eating bigger portions less often seems to cause weight gain more than eating smaller portions more frequently. One explanation to this observation may be the greater insulin secretion associated with eating larger meals.

\section{f) Restrained Eating}

Restrained eating is a common practice in many, if not most, middle-aged women of normal weight, characterized by conscious limitation of food intake. Greater increases in restraint correlate with greater weight loss but also with a higher risk of lapses, loss of control, and overeating. 


\section{g) Binge Eating Disorder}

Binge eating disorder is a psychiatric illness that primarily affects women. It is characterized by uncontrolled episodes of usually evening time eating.

\section{h) Night-Eating Syndrome}

Night-eating syndrome is the consumption of at least $25 \%$ of the total daily energy consumed between the evening meal and the following morning. It may be related to sleep disturbances, and may be a component of sleep apnea.

\section{Psychological and Social Factors}

Seasonal affective disorder is a type of depression that occurs during the winter in some individuals living in the north, possibly associated with shorter days. Patients with this condition have a tendency to gain weight during the winter. It can be treated effectively by high intensity artificial light in the winter. Attempts to link a personality type to the development of obesity have been unsuccessful.

\section{Socioeconomic and Ethnic Factors}

Obesity is more prevalent in lower socioeconomic groups in the United States. Although African-American women of all ages are more obese than Caucasian women, the association between socioeconomic status and being overweight or obese is much greater in the latter group. The relationship between the socioeconomic status and obesity is generally far less pronounced in men. ${ }^{37}$

\section{Conditions Associated with Obesity}

Obesity is estimated to be responsible for approximately 100,000-300,000 deaths annually in the United States. A Prospective Studies Collaboration analysis of 57 prospective studies, where 894,000 individuals were followed for a mean of eight years, showed that mortality is lowest among men and women with a BMI between 22.5 and 25 $\mathrm{kg} / \mathrm{m}^{2}$, and there is a $30 \%$ increase in overall mortality for each $5 \mathrm{~kg} / \mathrm{m}^{2}$ increase in BMI. ${ }^{3}$ Obesity-related deaths are mostly caused by increased deaths from heart disease, diabetes, hypertension and cancer.

\section{Morbidity Related to Adipose Tissue Hyperplasia / Hypertrophy}

These conditions can be listed as metabolic syndrome, diabetes, cardiovascular disease and hypertension, gallbladder disease, and cancer. Specifically, central obesity has been associated with an inflammatory milieu, which may lead to insulin resistance, impaired glucose tolerance or diabetes, dyslipidemia, including high levels of triglycerides and markers of inflammation (e.g. C-reactive protein), hyperuricemia, hypertension, impaired coagulation, and vasculoendothelial dysfunction. Weight loss of $\sim 16 \%$ in obese individuals dramatically increases recovery from many of these conditions, ${ }^{38}$ and beneficial effects start to be seen by losing as low as $10 \mathrm{lbs}$. In addition, the prevalence of gall stones sharply increases with weight gain, which may be a product of increased cholesterol levels and excretions serving as nidation factors for stone formation in the gallbladder. Furthermore, rates of cancer of the endometrium, breast, colon, and gallbladder are increased in obese women. This is explained in part by increased aromatization of androgens into estrogens, which serve 
as a mitogenic factor for some of these tissues, by the adipose tissue.

\section{Morbidity Attributed Directly to Fat Tissue}

Sleep apnea is prevalent in overweight/obese individuals, characterized by intermittent airway obstruction that interrupts sleep and causes hypoxemia. Increased fat mass in the pharyngeal area is one explanation for this condition. Degenerative osteoarthritis is one of the most costly and debilitating consequences of obesity, and generally progresses with age. Social stigmatization is another direct consequence of obesity, which probably affects women more than men, creating self-confidence and quality of life problems.

\section{Reproductive Performance}

Many studies have reported an association between increased BMI and infertility, most commonly related to ovulatory dysfunction, although decreased spontaneous pregnancy rates and increased time to pregnancy was also reported even among ovulatory obese women. ${ }^{39,40,41}$ Obesity may also have a negative impact on the outcome of treatment of infertility. Some studies show poorer outcomes of infertility treatment in these women, ${ }^{42}$ while others suggest that outcomes are comparable to non-obese women but higher doses of ovulation-inducing agents need to be used. ${ }^{43,44} \mathrm{~A}$ systematic review of 11 observational studies addressed the impact of obesity on the outcome of assisted reproductive technologies, i.e., in vitro fertilization. Overall, overweight women had a lower likelihood of pregnancy, increased risk of miscarriage, reduced number of oocytes retrieved, and higher doses of gonadotropins were needed. In this review, there was insufficient evidence for a correlation between obesity and live birth and cycle cancellation rates, as well as ovarian hyperstimulation syndrome development rate, ${ }^{45}$ although individual studies reported conflicting results. ${ }^{46,47,48}$

Obesity is associated with various complications during pregnancy, including gestational and overt diabetes, pregnancy associated hypertension, preterm delivery, postterm pregnancy, urinary tract infections, and sleep apnea. It is logical to consider the combination of two hypercoagulable states, pregnancy and obesity, as a compounded hypercoagulable and prothrombotic state. ${ }^{49}$ Obese women have longer labors characterized by prolongation of the active phase of labor, are more likely to have labor induction, ${ }^{50,51,52}$ are more likely to fail vaginal birth attempt after cesarean delivery with an increased risk of uterine dehiscence/rupture, ${ }^{53,54,55,56}$ and are more likely to have macrosomic infants with associated intrapartum complications (shoulder dystocia, malpresentation, hemorrhage, and fourth degree laceration). ${ }^{57,58,59,60}$ There are many intra- and post-operative concerns surrounding cesarean delivery with obese women, including emergency delivery, prolonged incisionto-delivery interval, blood loss $>1000 \mathrm{ml}$, longer operative times, among others. $^{53,57,58,61,62}$ The type of incision should be decided carefully secondary to the presence of large pannus and caudal displacement of umbilicus. Complications due to anesthesia are more common, both for regional 
(challenging placement of spinal anesthesia or epidural catheter) or general anesthesia (challenging endotracheal intubation, increased risk of aspirating stomach contents, avoiding premature extubation). ${ }^{62,63,64,65}$ Obese gravid is at higher risk for postpartum infection (wound, episiotomy, and endometritis) regardless of the mode of delivery and despite the use of antibiotic prophylaxis. ${ }^{57,58,59,62,66,67}$ There are conflicting data about the effect of obesity on lactation and postpartum bleeding. Some studies suggested an increased risk of failure to initiate lactation and a decreased duration of lactation in obese women, $68,69,70,71,72$ whereas others failed to identify a similar relationship. ${ }^{73,74}$ Similarly, a large population-based cohort study reported a $44 \%$ increased risk for major postpartum hemorrhage in obese gravidas, ${ }^{57}$ whereas several small studies did not find such an association. ${ }^{59,75,76}$

Maternal obesity is associated with a small increase in the absolute rate of some congenital anomalies, including neural tube defects, cardiovascular anomalies, cleft lip and palate, anorectal atresia, hydrocephaly, and limb reduction anomalies, whereas the risk of gastroschisis was significantly reduced. ${ }^{77,78,79}$ Also, the typical reduction in neural tube defect risk associated with standard doses of folic acid supplementation was reported to not occur in obese women. ${ }^{80}$ There are several confounders that may have an impact on these findings. Among those are increased prevalence of diabetes among obese women, and increased difficulty in diagnosing congenital anomalies in obese women, probably leading to more affected liveborns in this population. Risk of stillbirth and neonatal death were also reported to be higher in obese women. ${ }^{81,82}$ In addition to shoulder dystocia, fetal macrosomia may also predispose the neonate to obesity later in life, based on epidemiologic studies. ${ }^{83,84,85,86}$

For prevention of obesity-related complications during pregnancy, the best strategy is weight loss before conception. Despite the challenges associated with weight loss, it should continue to be encouraged as a primary preventive strategy in this population.

\section{Conclusions and Comments}

Obesity is an epidemic fueled by sedentary life style, abundance of food, unhealthy dietary habits, and other factors. Epidemiologic indicators predict worsening of the situation in the forthcoming years, leading to a chain reaction of increases in several morbidities and mortality. Prevention is the best strategy to avoid morbidity and mortality associated with obesity. Obstetricians and gynecologists have a unique position in this respect. As a primary care provider, he/she can not only use the regular office visit as an opportunity to screen for obesity and encourage proper diet, physical activity, and weight control, but also help manage underlying disorders that lead to obesity. Preconceptional visits are another excellent opportunity to help an overweight woman begin a weight loss program before she gets pregnant. By doing so, both maternal and fetal health may be protected and improved, allowing a better start and a healthier life for future generations. 


\section{References}

1. Clinical Guidelines on the Identification, Evaluation, and Treatment of Overweight and Obesity in Adults--The Evidence Report. National Institutes of Health. Obes Res. 1998 Sep;6 Suppl 2:51S-209S. Review. Erratum in: Obes Res 1998 Nov;6(6):464.

2. Obesity: preventing and managing the global epidemic. Report of a WHO consultation. World Health Organ Tech Rep Ser. 2000;894:i-xii, 1-253.

3. Prospective Studies Collaboration, Whitlock G, Lewington S, Sherliker P, Clarke R, Emberson J, Halsey J, Qizilbash N, Collins R, Peto R. Bodymass index and cause-specific mortality in 900000 adults: collaborative analyses of 57 prospective studies. Lancet. 2009 Mar 28;373(9669):108396. Epub 2009 Mar 18.

4. Peeters A, Barendregt JJ, Willekens F, Mackenbach JP, Al Mamun A, Bonneux L; NEDCOM, the Netherlands Epidemiology and Demography Compression of Morbidity Research Group. Obesity in adulthood and its consequences for life expectancy: a lifetable analysis. Ann Intern Med. 2003 Jan 7;138(1):24-32.

5. Fontaine KR, Redden DT, Wang C, Westfall AO, Allison DB. Years of life lost due to obesity. JAMA. 2003 Jan 8;289(2):187-93.

6. Vasan RS, Pencina MJ, Cobain M, Freiberg MS, D'Agostino RB. Estimated risks for developing obesity in the Framingham Heart Study. Ann Intern Med. 2005 Oct 4;143(7):473-80.

7. Centers for Disease Control and Prevention (CDC). Vital signs: statespecific obesity prevalence among adults --- United States, 2009. MMWR Morb Mortal Wkly Rep. 2010 Aug 6;59(30):951-5.
8. Leibel RL, Rosenbaum M, Hirsch J. Changes in energy expenditure resulting from altered body weight. $\mathrm{N}$ Engl J Med. 1995 Mar 9;332(10):621-8. Erratum in: N Engl J Med 1995 Aug 10;333(6):399.

9. Bray, G.A. Pathogenesis of obesity. 2009. In: UpToDate, 2010;18.3. Available from: http://www.uptodate.com/online/content/ topic.do?topicKey=obesity/6482\&selecte dTitle $=8 \% 7 \mathrm{E} 150 \&$ source $=$ search result \#H8.

10. Bray, George A. Contemporary diagnosis and management of obesity. $2^{\text {nd }}$ ed. Newtown, PA : Handbooks in Health Care Co.; 2003.

11. Rankinen T, Pérusse L, Weisnagel SJ, Snyder EE, Chagnon YC, Bouchard C. The human obesity gene map: the 2001 update. Obes Res. 2002 Mar;10(3):196-243.

12. Stunkard AJ, Harris JR, Pedersen NL, McClearn GE. The body-mass index of twins who have been reared apart. $\mathrm{N}$ Engl J Med. 1990 May 24;322(21):14837.

13. Stunkard AJ, Sørensen TI, Hanis C, Teasdale TW, Chakraborty R, Schull WJ, Schulsinger F. An adoption study of human obesity. N Engl J Med. 1986 Jan 23;314(4):193-8.

14. Bouchard C, Tremblay A, Després JP, Nadeau A, Lupien PJ, Thériault G, Dussault J, Moorjani S, Pinault S, Fournier $\mathrm{G}$. The response to long-term overfeeding in identical twins. $\mathrm{N}$ Engl $\mathrm{J}$ Med. 1990 May 24;322(21):1477-82.

15. Parfrey PS, Davidson WS, Green JS. Clinical and genetic epidemiology of inherited renal disease in Newfoundland. Kidney Int. 2002 Jun;61(6):1925-34. 
16. Ohta T, Gray TA, Rogan PK, Buiting K, Gabriel JM, Saitoh S, Muralidhar B, Bilienska B, Krajewska-Walasek M, Driscoll DJ, Horsthemke B, Butler MG, Nicholls RD. Imprinting-mutation mechanisms in Prader-Willi syndrome. Am J Hum Genet. 1999 Feb;64(2):397413.

17. Cassidy SB, Schwartz S. Prader-Willi and Angelman syndromes. Disorders of genomic imprinting. Medicine (Baltimore). 1998 Mar;77(2):140-51.

18. Crinò $A$, Schiaffini $R$, Ciampalini $P$, Spera S, Beccaria L, Benzi F, Bosio L, Corrias A, Gargantini L, Salvatoni A, Tonini G, Trifirò G, Livieri C; Genetic Obesity Study Group of Italian Society of Pediatric endocrinology and diabetology(SIEDP). Hypogonadism and pubertal development in Prader-Willi syndrome. Eur J Pediatr. 2003 May;162(5):327-33.

19. Ravussin E, Swinburn BA. Pathophysiology of obesity. Lancet. 1992 Aug 15;340(8816):404-8.

20. Rissanen AM, Heliövaara $M$, Knekt $P$, Reunanen A, Aromaa A. Determinants of weight gain and overweight in adult Finns. Eur J Clin Nutr. 1991 Sep;45(9):419-30.

21. Gillman MW, Rifas-Shiman SL, Camargo CA Jr, Berkey CS, Frazier AL, Rockett HR, Field AE, Colditz GA. Risk of overweight among adolescents who were breastfed as infants. JAMA. 2001 May 16;285(19):2461-7.

22. Bray GA. Weight control: assessment and management. In: Stenchever M, editor. Clinical updates in women's health care. Washington, DC: ACOG, 2006.

23. Rotterdam ESHRE/ASRM-Sponsored PCOS consensus workshop group. Revised 2003 consensus on diagnostic criteria and long-term health risks related to polycystic ovary syndrome (PCOS).
24. Hum Reprod. 2004 Jan;19(1):41-7. Azziz R, Woods KS, Reyna R, Key TJ, Knochenhauer ES, Yildiz BO. The prevalence and features of the polycystic ovary syndrome in an unselected population. J Clin Endocrinol Metab. 2004 Jun;89(6):2745-9.

25. Knochenhauer ES, Key TJ, KahsarMiller M, Waggoner W, Boots LR, Azziz R. Prevalence of the polycystic ovary syndrome in unselected black and white women of the southeastern United States: a prospective study. J Clin Endocrinol Metab. 1998 Sep;83(9):3078-82.

26. Azziz R, Sanchez LA, Knochenhauer ES, Moran C, Lazenby J, Stephens KC, Taylor K, Boots LR. Androgen excess in women: experience with over 1000 consecutive patients. J Clin Endocrinol Metab. 2004 Feb;89(2):453-62.

27. Flegal KM, Troiano RP, Pamuk ER, Kuczmarski RJ, Campbell SM. The influence of smoking cessation on the prevalence of overweight in the United States. N Engl J Med. 1995 Nov 2;333(18):1165-70.

28. O'Hara P, Connett JE, Lee WW, Nides M, Murray R, Wise R. Early and late weight gain following smoking cessation in the Lung Health Study. Am J Epidemiol. 1998 Nov 1;148(9):821-30.

29. Williamson DF, Madans J, Anda RF, Kleinman JC, Kahn HS, Byers T. Recreational physical activity and tenyear weight change in a US national cohort. Int J Obes Relat Metab Disord. 1993 May;17(5):279-86.

30. Lee IM, Djoussé L, Sesso HD, Wang L, Buring JE. Physical activity and weight gain prevention. JAMA. 2010 Mar 24;303(12):1173-9.

31. Swinburn B, Shelly A. Effects of TV time and other sedentary pursuits. Int $\mathrm{J}$ Obes (Lond). 2008 Dec;32 Suppl 7:S132-6. 
32. Robinson TN. Reducing children's television viewing to prevent obesity: a randomized controlled trial. JAMA. 1999 Oct 27;282(16):1561 7 .

33. Bray GA, Popkin BM. Dietary fat intake does affect obesity! Am J Clin Nutr. 1998 Dec;68(6):1157-73.

34. Roberts SB, Pi-Sunyer FX, Dreher M, Hahn R, Hill JO, Kleinman RE, Peters JC, Ravussin E, Rolls BJ, Yetley E, Booth SL. Physiology of fat replacement and fat reduction: effects of dietary fat and fat substitutes on energy regulation. Nutr Rev. 1998 May;56(5 Pt 2):S29-41; discussion S41-9.

35. Ludwig DS, Peterson KE, Gortmaker SL. Relation between consumption of sugar-sweetened drinks and childhood obesity: a prospective, observational analysis. Lancet. $2001 \quad$ Feb 17;357(9255):505-8.

36. Davies KM, Heaney RP, Recker RR, Lappe JM, Barger-Lux MJ, Rafferty K, Hinders S. Calcium intake and body weight. J Clin Endocrinol Metab. 2000 Dec;85(12):4635-8.

37. Hedley AA, Ogden CL, Johnson CL, Carroll MD, Curtin LR, Flegal KM. Prevalence of overweight and obesity among US children, adolescents, and adults, 1999-2002. JAMA. 2004 Jun 16;291(23):2847-50.

38. Sjöström L, Lindroos AK, Peltonen $M$, Torgerson J, Bouchard C, Carlsson B, Dahlgren S, Larsson B, Narbro K, Sjöström CD, Sullivan $M$, Wedel $H$; Swedish Obese Subjects Study Scientific Group. Lifestyle, diabetes, and cardiovascular risk factors 10 years after bariatric surgery. N Engl J Med. 2004 Dec 23;351(26):2683-93.

39. Gesink Law DC, Maclehose RF, Longnecker MP. Obesity and time to pregnancy. Hum Reprod. 2007 Feb;22(2):414-20. Epub 2006 Nov 9.

40. Ramlau-Hansen $\mathrm{CH}$, Thulstrup AM, Nohr EA, Bonde JP, Sørensen TI, Olsen J. Subfecundity in overweight and obese couples. Hum Reprod. 2007 Jun;22(6):1634-7. Epub 2007 Mar 7.

41. van der Steeg JW, Steures P, Eijkemans MJ, Habbema JD, Hompes PG, Burggraaff JM, Oosterhuis GJ, Bossuyt PM, van der Veen F, Mol BW. Obesity affects spontaneous pregnancy chances in subfertile, ovulatory women. Hum Reprod. 2008 Feb;23(2):324-8. Epub 2007 Dec 11.

42. Wang JX, Davies M, Norman RJ. Body mass and probability of pregnancy during assisted reproduction treatment: retrospective study. BMJ. 2000 Nov 25;321(7272):1320-1.

43. Balen AH, Platteau P, Andersen AN, Devroey $P$, Sørensen $P$, Helmgaard L, Arce JC. The influence of body weight on response to ovulation induction with gonadotrophins in 335 women with World Health Organization group II anovulatory infertility. BJOG. 2006 Oct;113(10):1195-202. Epub 2006 Aug 10.

44. Al-Azemi M, Omu FE, Omu AE. The effect of obesity on the outcome of infertility management in women with polycystic ovary syndrome. Arch Gynecol Obstet. 2004 Dec;270(4):20510.

45. Maheshwari A, Stofberg L, Bhattacharya S. Effect of overweight and obesity on assisted reproductive technology--a systematic review. Hum Reprod Update. 2007 SepOct;13(5):433-44. Epub 2007 Jun 21.

46. Dokras A, Baredziak L, Blaine J, Syrop C, VanVoorhis BJ, Sparks A. Obstetric outcomes after in vitro fertilization in obese and morbidly obese women. Obstet Gynecol. 2006 Jul;108(1):61-9.

47. Fedorcsák $\mathrm{P}$, Storeng R, Dale PO, Tanbo T, Abyholm T. Obesity is a risk factor for early pregnancy loss after IVF or ICSI. Acta Obstet Gynecol Scand. 2000 Jan;79(1):43-8. 
48. Styne-Gross A, Elkind-Hirsch K, Scott RT Jr. Obesity does not impact implantation rates or pregnancy outcome in women attempting conception through oocyte donation. Fertil Steril. 2005 Jun;83(6):1629-34.

49. Duhl AJ, Paidas MJ, Ural SH, Branch W, Casele H, Cox-Gill J, Hamersley SL, Hyers TM, Katz V, Kuhlmann R, Nutescu EA, Thorp JA, Zehnder JL; Pregnancy and Thrombosis Working Group. Antithrombotic therapy and pregnancy: consensus report and recommendations for prevention and treatment of venous thromboembolism and adverse pregnancy outcomes. Am J Obstet Gynecol. 2007 Nov;197(5):457.e1-21.

50. Buhimschi CS, Buhimschi IA, Malinow AM, Weiner CP. Intrauterine pressure during the second stage of labor in obese women. Obstet Gynecol. 2004 Feb;103(2):225-30. Erratum in: Obstet Gynecol. 2004 May;103(5 Pt 1):1019.

51. Nuthalapaty FS, Rouse DJ, Owen J. The association of maternal weight with cesarean risk, labor duration, and cervical dilation rate during labor induction. Obstet Gynecol. 2004 Mar;103(3):452-6. Erratum in: Obstet Gynecol. 2004 May;103(5 Pt 1):1019.

52. Vahratian A, Zhang J, Troendle JF, Savitz DA, Siega-Riz AM. Maternal prepregnancy overweight and obesity and the pattern of labor progression in term nulliparous women. Obstet Gynecol. 2004 Nov;104(5 Pt 1):943-51.

53. Chauhan SP, Magann EF, Carroll CS, Barrilleaux PS, Scardo JA, Martin JN Jr. Mode of delivery for the morbidly obese with prior cesarean delivery: vaginal versus repeat cesarean section. Am J Obstet Gynecol. 2001 Aug;185(2):34954.
54. Carroll CS Sr, Magann EF, Chauhan SP, Klauser CK, Morrison JC. Vaginal birth after cesarean section versus elective repeat cesarean delivery: Weight-based outcomes. Am J Obstet Gynecol. 2003 Jun;188(6):1516-20; discussion 1520-2.

55. Bujold E, Hammoud A, Schild C, Krapp M, Baumann $P$. The role of maternal body mass index in outcomes of vaginal births after cesarean. Am J Obstet Gynecol. 2005 Oct;193(4):151721.

56. Hibbard JU, Gilbert S, Landon MB, Hauth JC, Leveno KJ, Spong CY, Varner MW, Caritis SN, Harper $M$, Wapner RJ, Sorokin Y, Miodovnik M, Carpenter M, Peaceman AM, O'Sullivan MJ, Sibai BM, Langer O, Thorp JM, Ramin SM, Mercer BM, Gabbe SG; National Institute of Child Health and Human Development Maternal-Fetal Medicine Units Network. Trial of labor or repeat cesarean delivery in women with morbid obesity and previous cesarean delivery. Obstet Gynecol. 2006 Jul;108(1):125-33.

57. Sebire NJ, Jolly $M$, Harris JP, Wadsworth J, Joffe M, Beard RW, Regan L, Robinson S. Maternal obesity and pregnancy outcome: a study of 287,213 pregnancies in London. Int $\mathrm{J}$ Obes Relat Metab Disord. 2001 Aug;25(8):1175-82.

58. Edwards LE, Dickes WF, Alton IR, Hakanson EY. Pregnancy in the massively obese: course, outcome, and obesity prognosis of the infant. Am J Obstet Gynecol. 1978 Jul 1;131(5):47983.

59. Bianco AT, Smilen SW, Davis Y, Lopez S, Lapinski R, Lockwood CJ. Pregnancy outcome and weight gain recommendations for the morbidly obese woman. Obstet Gynecol. 1998 Jan;91(1):97-102. 
60. Jensen DM, Damm P, Sørensen B, Mølsted-Pedersen L, Westergaard JG, Ovesen P, Beck-Nielsen H. Pregnancy outcome and prepregnancy body mass index in 2459 glucose-tolerant Danish women. Am J Obstet Gynecol. 2003 Jul;189(1):239-44.

61. Cnattingius S, Bergström R, Lipworth L, Kramer MS. Prepregnancy weight and the risk of adverse pregnancy outcomes. N Engl J Med. 1998 Jan $15 ; 338(3): 147-52$.

62. Perlow JH, Morgan MA. Massive maternal obesity and perioperative cesarean morbidity. Am J Obstet Gynecol. 1994 Feb;170(2):560-5.

63. Ranta $P$, Jouppila $P$, Spalding $M$, Jouppila $R$. The effect of maternal obesity on labour and labour pain. Anaesthesia. 1995 Apr;50(4):322-6.

64. Hood DD, Dewan DM. Anesthetic and obstetric outcome in morbidly obese parturients. Anesthesiology. 1993 Dec;79(6):1210-8.

65. Soens MA, Birnbach DJ, Ranasinghe JS, van Zundert A. Obstetric anesthesia for the obese and morbidly obese patient: an ounce of prevention is worth more than a pound of treatment. Acta Anaesthesiol Scand. 2008 Jan;52(1):619.

66. Robinson HE, O'Connell CM, Joseph KS, McLeod NL. Maternal outcomes in pregnancies complicated by obesity. Obstet Gynecol. 2005 Dec;106(6):135764.

67. Myles TD, Gooch J, Santolaya J. Obesity as an independent risk factor for infectious morbidity in patients who undergo cesarean delivery. Obstet Gynecol. 2002 Nov;100(5 Pt 1):959-64.

68. Chapman DJ, Pérez-Escamilla R. Identification of risk factors for delayed onset of lactation. J Am Diet Assoc. 1999 Apr;99(4):450-4; quiz 455-6.

69. Hilson JA, Rasmussen KM, Kjolhede CL. Maternal obesity and breast feeding success in a rural population of white women. Am J Clin Nutr. 1997 Dec;66(6):1371-8. Erratum in: Am J Clin Nutr 1998 Mar;67(3):494.

70. Li R, Jewell S, Grummer-Strawn L. Maternal obesity and breast-feeding practices. Am J Clin Nutr. 2003 Apr;77(4):931-6.

71. Rasmussen KM, Hilson JA, Kjolhede $\mathrm{CL}$. Obesity as a risk factor for failure to initiate and sustain lactation. Adv Exp Med Biol. 2002;503:217-22.

72. Rutishauser IH, Carlin JB. Body mass index and duration of breast feeding: a survival analysis during the first six months of life. J Epidemiol Community Health. 1992 Dec;46(6):559-65.

73. Michaelsen KF, Larsen PS, Thomsen BL, Samuelson G. The Copenhagen cohort study on infant nutrition and growth: duration of breast feeding and influencing factors. Acta Paediatr. 1994 Jun;83(6):565-71.

74. Riva E, Banderali G, Agostoni C, Silano M, Radaelli G, Giovannini M. Factors associated with initiation and duration of breastfeeding in Italy. Acta Paediatr. 1999 Apr;88(4):411-5.

75. Calandra C, Abell DA, Beischer NA. Maternal obesity in pregnancy. Obstet Gynecol. 1981 Jan;57(1):8-12.

76. Gross T, Sokol RJ, King KC. Obesity in pregnancy: risks and outcome. Obstet Gynecol. 1980 Oct;56(4):446-50.

77. Rasmussen SA, Chu SY, Kim SY, Schmid CH, Lau J. Maternal obesity and risk of neural tube defects: a metaanalysis. Am J Obstet Gynecol. 2008 Jun;198(6):611-9.

78. Stothard KJ, Tennant PW, Bell R, Rankin J. Maternal overweight and obesity and the risk of congenital anomalies: a systematic review and meta-analysis. JAMA. 2009 Feb 11;301(6):636-50. 
79. Gilboa SM, Correa A, Botto LD, Rasmussen SA, Waller DK, Hobbs CA, Cleves MA, Riehle-Colarusso TJ; National Birth Defects Prevention Study. Association between prepregnancy body mass index and congenital heart defects. Am J Obstet Gynecol. 2010 Jan;202(1):51.e1-51.e10. Epub 2009 Oct 1.

80. Werler MM, Louik C, Shapiro S, Mitchell AA. Prepregnant weight in relation to risk of neural tube defects. JAMA. 1996 Apr 10;275(14):1089-92.

81. Chu SY, Kim SY, Lau J, Schmid CH, Dietz PM, Callaghan WM, Curtis KM. Maternal obesity and risk of stillbirth: a metaanalysis. Am J Obstet Gynecol. 2007 Sep;197(3):223-8.

82. Chen A, Feresu SA, Fernandez C, Rogan WJ. Maternal obesity and the risk of infant death in the United States. Epidemiology. 2009 Jan;20(1):74-81.

83. Kliegman RM, Gross T. Perinatal problems of the obese mother and her infant. Obstet Gynecol. 1985 Sep;66(3):299-306.

84. Silliman K, Kretchmer N. Maternal obesity and body composition of the neonate. Biol Neonate. 1995;68(6):38493.

85. Whitelaw AG. Influence of maternal obesity on subcutaneous fat in the newborn. Br Med J. 1976 Apr 24;1(6016):985-6.

86. Hull HR, Dinger MK, Knehans AW, Thompson DM, Fields DA. Impact of maternal body mass index on neonate birthweight and body composition. Am J Obstet Gynecol. 2008 Apr;198(4):416.e1-6. Epub 2008 Feb 15. 